\title{
STRATEGIC CHOICES OF RUSSIA AND BARGAIN FOR EUROPEAN SECURITY ARCHITECTURE: BRINGING BACK THE BIPOLARITY
}

\section{AVETIK PASHAYAN}

Research Scholar, Department of Political Science and Public Administration, Shandong University, Jinan, China

\begin{abstract}
The article examines the strategic choices and moves of the Russian Federation relating to the architecture of the European security system. It analyzes the Russian strategic choices made for its adjustment within the system during the two waves of the launched bargain for the architecture of the European security system. The evolving Russia - West relationships reflect the Russian strategic choices and the bargain, while during the first wave, Russia was betting on its institutionalized integration to the political West with hierarchical architecture of the European security, having the OSCE as the central pillar of the system.. During the second wave, Russian strategic choice was more about the strengthening of the existing status quo in the post-Soviet space with two-pillared architecture of the European security. By the establishment of the Eurasian community alongside the Euro-Atlantic one, inevitably, the bipolar 'New Yalta' styled system comes back.
\end{abstract}

KEYWORDS: Russia, ESS, Security, Bargain, CSCE, OSCE, NATO \&EU

Received: Nov02, 2019; Accepted: Nov22, 2019; Published: Dec24, 2019; PaperId.: IJPSLIRJUN20201

\section{INTRODUCTION}

Since the end of the Cold War, Russian adjustment within the European security system (ESS) is very dynamic and consistently debatable. The defence and promotion of its very security interests were and are sometimes inconsistent and even overlapping with the interests of its neighbors. Russia's efficient and organic integration into the ESS without overstepping the interests of others, and, at the same time, defending its own interests without losing its power remains on the agenda. All these are having a central significance, particularly for Russia. Since the end of the Cold War, it was engaged in the bargain for the architecture of the ESS, making strategic choices needed for its adjustment. Since the very beginning of the 1990s, one of the main goals of the Russian Federation was to establish a dominant system that should cover the security affairs of the European continent, where it could be a full member and a partner in decision-making procedures, especially regarding the use of force and further implementation of it if needed; in a short system, where Russia will have its chair among the decision-makers. Since the end of the Cold War, two waves of the bargain for the architecture of ESS were launched. While two waves took place in the evolving external environment, the Russian strategic choices evolved too.

\section{FIRST WAVE OF BARGAIN AND RUSSIAN CHOICE OF THE 1990S FOR THE INTEGRATION TO THE POLITICAL WEST}

The Russian politics of the first half of the 1990s were directed towards establishing an equal strategic partnership with the countries of the Euro-Atlantic community in the interests of the Russian Federation. The emphasis was put on the realization of the national interests through cooperation and compromise, not confrontation. Such cooperation should develop based on shared values, and presumably, Russia could take full advantage of the world 
developed markets at that period. In the 1990s, an unprecedented level of cooperation was reached between the United States (US) and Russia, regarding the strategic maintenance stability in the face of the reduction of their nuclear arsenals. Also, both sides were working very closely together in the framework of the contact group of the Former Yugoslavia (Zagorski, 2017).

Despite the unprecedented cooperation since the beginnings of the 1990s, the institutional gap between Russia and West was noted by Moscow. Russia was not a part of the activities that were taking place in the North Atlantic Treaty Organization (NATO) and Group of Seven (G7). ${ }^{2}$ During that period, Moscow highlighted and suggested to concentrate their efforts on specific issues. So, except for the discussions on mechanisms of informing Russia and Western countries about their decisions that were achieved earlier, Russia was seeking a prior agreement on the approaches before making final decisions, thereby ensuring that interests and concerns of both are taken into account and made on a mutual basis (Zagorski, 2017).

In 1993, Russia suggested to step up activities of the North Atlantic Cooperation Council (NACC), however, under the auspices of CSCE instead of NATO. The Russian approach here was to create an equal partnership between the Commonwealth of Independent States (CIS), NACC, European Union (EU), Council of Europe, and at that time Western Economic Union (WEU), whose overall activities would be coordinated by CSCE. Hence, the Russian approach was in favor of the hierarchical architecture of European security with the lead, and overarching authority of CSCE. Practically, at the same time, with the proposal of the reorganization of the NACC, the Ministry of Foreign Affairs of Russia made a proposal on the further strengthening of the institutions and structures of the CSCE, made after 1990. Mainly, the proposal was about to establish a committee of permanent representatives of party states and to move the secretariat from Prague to Vienna (Zagorski, 2017). ${ }^{3}$

In 1994, Russia made new proposals, targeting the strengthening of the CSCE for the discussions in preparation for the Budapest CSCE Summit. Later on, they were developed into the "program on the improvement of the effectiveness of the CSCE."Russia was proposing to cement the central role of the organization in peacekeeping, strengthening democracy, ensuring security, stability in the CSCE covering area, turn it into a full-fledged regional organization with its own charter, enhance the role of the CSCE as a leading UN partner in conflict resolutions of the region, develop and specify the CSCE framework coherency with the UN with a focus on cooperation in preventive diplomacy and peacekeeping. The Russian proposal on the "program on the improvement of the effectiveness of the CSCE" was to establish the executive committee analogical to the UN Security Council (UNSC), comprising no more than 10-member states with both statuses, permanent and temporary, with Russia being among the permanent members. Credentials of a committee led by the Chairman-in-Office of the CSCE would be reaffirmed annually by the Council of Foreign Ministers, and the decisions would be made with consensus, having a binding character. ${ }^{4}$ Russia also came out with the idea for coordination activity between CIS and CSCE. This proposal is particularly important, as it was presuming to the limitation

\footnotetext{
${ }^{1}$ These shared values were addressing the partnership and interactions of the democratic states, united by shared values and like-minded states that are adherent to shared democratic values and norms of United Nations (UN) and Conference on Security and Cooperation in Europe (CSCE).

${ }^{2}$ The Russian point here was that, nonetheless, the G7 is not the only and major international institution, anyway, its members coordinate their political and economic policies.

${ }^{3}$ Both of them were achieved.

${ }^{4}$ Russia was also proposing to strengthen the role of 'troika' of CSCE and to create regional committees dealing with regional security, cooperation, and stability.
} 
of the areas of responsibility and activities of two organizations in the post-Soviet space. Russia, on the one hand, was seeking the CSCE's help for serving its interests, particularly concerning the peacekeeping activities of Russia in the postSoviet countries, ${ }^{5}$ and getting support concerning the situation of the Russian population of Estonia and Latvia. On the other hand, Moscow was skeptical regarding the engagement of the CSCE in solving the issues of the post-soviet space, considering this area as a sphere of its privileged interests and responsibility (Zagorski, 2017).

The Russian proposal of the establishment of the executive committee for CSCE caused mixed reactions. Mainly, the adverse reaction was caused by the ideational framework of the creation of the closed 'club' of permanent and temporary members within the committee, where the decisions made would be binding for the overall organization. ${ }^{6}$ There was a broad spectrum of proposals from other memberships addressing the Russian proposal; nonetheless, most of them were different in form but were in favor of strengthening the role of the CSCE/Organization for Security and Cooperation in Europe (OSCE).The important part is that these discussions were initiated generally at the same time with the NATO's enlargement eastward, which partially contributed to the marginalization of the OSCE, as the interest towards the OSCE as central pan-European organization in the ESS architecture started to decrease in favor of NATO by many states, and predominantly by the countries seeking to join the alliance. These emerging changes pushed Russia to shift the emphasis in its policy from strengthening the OSCE to institutionalizing mechanisms for making joint decisions with NATO and the EU (Zagorski, 2017).

Andrei Kelin, the permanent representative of Russia to OSCE from 2011 to 2015, in his interview, described these changes. He described it as a unilateral approach by Russia to bet on OSCE, as the adoption of the Charter of Paris and following CSCE/OSCE documents and perception, or the point of view that the OSCE could replace relationships with NATO, was not shared by the western counterparts. The OSCE was directed mainly to the human rights and arms control dimension, and with the decline of interest towards the arms control, the other formats came into the agenda, particularly the Russia-NATO Council-EU (Kelin, 2015).This maneuver in Russian politics further marginalized the OSCE.

Since 1992, and particularly from 1994 to 1999, within the framework of CSCE/OSCE key documents, particularly, the Code of Conduct on Politico-Military Aspects of Security from CSCE Budapest Document 1994, the Framework for Arms Control from Lisbon Document 1996, the Charter for European Security from Istanbul Document 1999 were achieved on the model of shared and comprehensive security for $21^{\text {st }}$ century Europe. The discussions on the model were finalized in the Istanbul Document1999 (1999) and adoption of the Charter of European security, where based on Chapter 3 of the Charter, 'the refusal of hierarchical architecture of the European security was confirmed, and 'Net' cooperation established(Art. 12).With this, the first wave of the bargain for European security architecture ended.

In the $1990 \mathrm{~s}$, there were both issues and contradictions in the policies, however, based on cooperation many of them were resolved, and the main achievement of that period was that despite diverging and contradicting approaches in different cases, the intensive dialogue between Russia, US, and other western countries were kept ongoing. There was a joint search for mutually acceptable solutions. The mainstream of the Russian strategy till the end of the 1990s in Europe

\footnotetext{
${ }^{5}$ Having this goal, in 1994 within the CSCE, the principles of carrying out the peacekeeping operation by the third party were discussed, that is, Russia in the CIS, under the auspices of the OSCE, but no consensus was reached on this issue. ${ }^{6}$ Even if these decisions needed to be confirmed by a qualified majority of participating States, anywaywould not require consensus.

${ }^{7}$ It is called the "The Platform for Co-Operative Security."
} 
was the institutionalization of relations with the EU, ${ }^{8}$ as well as strengthening the role of CSCE/OSCE as the central institution in the architecture of the $\operatorname{ESS}^{9}$ (Zagorski, 2017).

\section{The 2000s: Growing Alienation, Uncertainty and Mistrust}

New tendencies manifested in European politics in the mid-2000s contributed to the strengthening of anti-Western notes in Moscow's policy and the growth of mutual distrust. The considerable decrease noted in communications between Russia and the West as well as in the already forgotten practice of prior consultations before the decisions being made, ${ }^{10}$ given the Russian leadership perception that the West does not 'hear' them and do not take into account their concerns; as Vladimir Putin would mention in his response to the journalists regarding the deployment of the US anti-ballistic missile defense (ABMD) in Romania: "Nobody listens to us, nobody wants to negotiate with us, except for general phrases, we hear nothing" (Kremlin, 2016).In addition to these, the feeling of tiredness and frustration with each other in the relations between Russia and the West was mutual. The Western socio-political circles towards Russia were changing too. That process mostly started to form after the start of the second Chechen War in 1999, followed by the Duma elections of 2003 and particularly in 2007, with the amplification of authoritarian tendencies in Russian domestic politics (Zagorski, 2017).In his pronounced speech, Peter Mandelson (2007), the EU commissar on international trade, described the Russia-West relations very well, saying that the "level of misunderstanding or even mistrust we have not seen since the end of the Cold War."

Several events played an essential role in the formation of mutual distrust between Russia and the West. It was starting from December 2002, when Russia objected to prolong the mandate of OSCE mission in Chechnya. So, because of the lack of consensus, the mission was removed from there. The next big event took place in Bosnia and Herzegovina and Kosovo, in the summer of 2003, when Russia withdrew its contingent from the international stabilization forces led by NATO. Another indirect but crucial impact was the failure of the agreed framework of the settlement of the Transnistrian conflict, suggested by Russia, and refused by the EU and US to support the plan. This refusal seemed to Moscow that the West is gradually questioning the 'exclusive' role of Russia in the post-soviet conflict management, which was not in place in the 1990s. This perception was gaining more relevance among the Russian elite, having the background of Georgian and Moldovan persistent efforts to change the framework of the peacekeeping mission, aiming to exclude the Russian participation in them, or at least to minimize its influence (Zagorski, 2017).

The two waves of the EU and NATO enlargement eastwards and particularly the discussions in NATO on providing the plan to Georgia and Ukraine to join the alliance, were another substantial contributing factors to Russian dissatisfaction and alienation from the West. The discussions on joining the alliance culminated in April 2008, during the NATO summit in Bucharest. Nonetheless, because of the objection of France and Germany, a consensus was not reached, and the decision not made on the accession plan but in the adopted Bucharest Summit Declaration (2008), NATO welcomed the applications and contributions of Georgia and Ukraine towards the alliance and stated: "We agreed today that these countries will become members of NATO." (Art 23).

Another critical event playing a role in the worsening of relations between Russia and West was the assessment of

\footnotetext{
${ }^{8}$ In 1994, the agreement on partnership and cooperation was signed with the EU.

${ }^{9}$ The key decisions of the transformation of the CSCE/OSCE were achieved during the summits that took place from 1990 to 1999.

${ }^{10}$ Particularly, those that could relate to the Russian interests.
} 
the joint OSCE (2003)and Council of Europe's mission on the Russian Duma elections in December 2003, when the mission highlighted both positive and negative aspects of the elections. According to the former British ambassador to Moscow, Roderic Lyne (2015), the 2004 Duma elections was one of the focal points in Russia-West relations.

The 'colour revolutions' in the post-Soviet states were another contributing factor affecting the trust and break of the integration with the political West. In Russia, it is viewed and already convinced as principally, goal-oriented US-led policy towards the change of political regimes in the post-Soviet space, including Russia. So, the question of the relevance of the 'common shared values and interests,' its applicability and interpretation further deepen the Russian mistrust towards West.

The growing alienation between Russia and the West affected the gradual demise of the arms control regime. The two iconic Cold-War era treaties came to an end in this period. A start was given with the Anti-Ballistic Missile (ABM) Treaty of 1972. While Bush's administration stance after September 11, 2001, was that the US is building the nationwide defence to counter the threat from 'rogue states,' Russia continued to see the Treaty in the context of the US-Russian strategic nuclear balance in the logic of mutual assured destruction. From the Russian perspective, it was the US's unilateral approach to achieve self-security at the expense of others; therefore, it rejected any new framework of mixture deterrence and defense. Senior Russian officials persistently were emphasizing that the ABM Treaty remains a cornerstone of the US-Russian nuclear arms control regime, and the US withdrawal from it will lead to its collapse. Plus, there have been repeated warnings from the Russian side that the withdrawal will result in less transparency and technical countermeasures from Russia (Kile, 2001). ${ }^{11}$

After all, on December 13, 2001, the US withdraws from the Treaty, and President Bush announced that the withdrawal would not affect the US-Russian relationships and Russian security with any means. Contrary, Vladimir Putin called the decision of Bush as 'mistake' and called for quick moves to establish a "new framework of our strategic relationship."At the same time, Vladimir Putin, during his address to the nation on Russian television, stated that the US move "presents no threat to the security of the Russian Federation" (Perez-Rivas, 2001).Nonetheless, in 2018, during the interview in NewYork, Vladimir Putin, to the question related to whether the Russia and US are currently engaged in the arms race, answered that the arms race started when the US quit the ABM Treaty (TASS, 2018).

The next step leading to the demise of the arms control regime was the Russian suspension of the Conventional Armed Forces in Europe (CFE) Treaty in 2007, which started the erosion of the regime of CFE, and then the factual collapse of the system. De Facto Russia finalizes its withdrawal from the most comprehensive arms control treaty in European history in 2015because of “exceptional circumstances" that jeopardized Russia's "national interests in the sphere of military security." According to the Russian officials, including President Vladimir Putin, these exceptional circumstances are the challenges presented by NATO's enlargement towards Eastern Europe, construction of new military facilities there, unbalanced on-site inspections and development of ABMDs by the US as well as other types of weapons that were not initially included in the CFE Treaty. At the same time, Russian officials stated that they are ready to start the negotiations for a new analogous treaty, aiming to limit the CFE if their counterparts agree to start discussions(Weitz, 2015).

${ }^{11}$ The US European NATO allies, particularly France and Germany, expressed their disapproval on the US decision, highlighting that it could additionally complicate the relations with Russia and might cause a new nuclear arms race. 
In addition to all these, the unilateral declaration of independence of Kosovo in February 2008 and six days of Russo-Georgian war in August followed by Russian recognition of Abkhazia and South Ossetia further complicated the Russia-West relations. Nonetheless, they were not focal points, regarding the Russian integration into the political West, but they were affecting the socio-political support of West towards it (Zagorski, 2017).

In this period, the signs of emerging gaps and crises between Russia and the West became more evident. This period was different from the first one, with a decrease of intensity of dialogue and search of mutually acceptable decisions as well as with the gradual departure of Russia from the idea to complete the architecture of ESS through the inclusive integration of the political West. The difference in approaches became much more evident during the most recent Russian approach and proposal on the ESS architecture.

\section{SECOND WAVE OF BARGAIN AND RUSSIAN CHOICE OF STRENGTHENING THE EXISTING STATUS QUO}

The revival of dialogue between Russia and West was primarily facilitated by the 2008 elections. In 2008, in the West, there were hopes with the election of the Dmitri Medvedev as President of Russia, and in Russia, hopes were connected with the election of Barack Obama as the President of the US. ${ }^{12}$ Meanwhile, in West, the discussions on the perspectives of the Russian acceptance to Euro-Atlantic institutions were resumed; already, Russia lost interest, which was emphasized in the replies of top Russian officials on this resumption(Zagorski, 2017).

Alongside the revival of the dialogue between Russia and the West, the second wave of the bargain for the architecture of ESS was launched by Russia.

For the first time, on June 5, 2008, in Berlin, President Dmitri Medvedev announced the Russian proposal on the European Security Treaty (EST).Nonetheless, Russia was not in favor of discussing the Treaty within the OSCE framework, and it became apparent during the speech of Dmitri Medvedev at the University of Helsinki on April 20, 2009, when he mentioned that there is a need of new platform for discussions, as neither regional organizations, such as NATO, EU, Collective Security Treaty Organization (CSTO) or CIS nor OSCE are suitable but, multilateral informal talks and discussions were continued within the OSCE in Helsinki in December 2008 and were furtherly mostly carried out within the OSCE framework(Zagorski, 2009; Kremlin, 2009). ${ }^{13}$

For the first time, the more detailed version of the Treaty was proposed by the foreign minister Sergey Lavrov in June 2009 during the annual security-related conference of the OSCE. However, the final official draft of the Treaty was released by the Russian Federation before the annual ministerial meeting of OSCE in Athens at the end of June 2009.It was not discussed during the meeting; however, the samples were sent to the heads of the participating states and Chairmen and Secretaries-General of the OSCE, NATO, EU, CSTO and CIS. At the same time, the draft appeared on the official website of the Russian President on November 29, 2009 (Zagorski, 2017).

The draft has 14 articles. According to it, cooperation should be based on "the principles of indivisible, equal and undiminished security."Any security measures taken by any member of the Treaty individually or together with military

\footnotetext{
12 There were hopes in West that Medvedev will bring back Russia to domestic liberalization and based on that rapprochement with the West. From the Russian side, there were hopes that the new administration in the White House will reconsider the NATO-centrism and reconsider the US policy towards Russia.

${ }^{13}$ The explanation of Dmitri Medvedev was that not all states are members of the regional organizations, while OSCE is concentrated on more 'private' issues.
} 
coalition alliance or international organization should take into consideration the security interests of all the remaining party members of the Treaty(the draft of the European Security Treaty, 2009, Art. 1).Article 2.1 highlights that the Treaty members should not undertake or assist any activities or actions that could significantly affect the security interests of other Treaty Parties. Art. 2.2 highlights the need for all members of the military coalitions, alliances, or organizations to try to make sure that the respective collective bodies or entities, where they are part of, will be in compliance with the UN Charter, Declaration on Principles of International Law concerning friendly relations and cooperation among States following the UN Charter, Helsinki Final Act, Charter for European Security and other related OSCE documents as well as the Article 1 of this Treaty. Article 3 is about the raised concerns, transparency, as well as mutual trust. So, the Party-state has a right for the request to any other Party-state to provide data on any noteworthy administrative, legislative, or organizational measures, which according to the requesting Party-state, might have an effect on its security (interests).The parties might request to hold consultations and conferences, including the extraordinary ones, if disputes arise between them. Decisions should be made with consensus and be binding. In case of an armed attack or a threat of attack on the Treaty Party, the Depositary should take immediate actions to call an Extraordinary Conference of the Parties of the Treaty to determine the collective measures necessary for the settlement."Every Party shall be entitled to consider an armed attack against any other Party, an armed attack against itself" (The Draft of the European Security Treaty, 2009, Art. 7.2).During the exercise of the right of self- defense under Article 51 of the UN Charter, the Party-state might assist, including with military means to the attacked Party-state, with the latest consent. The Treaty should not have any effect on the rights and obligations of the Treaty-parties under the UN Charter as well as on the primary role of the UNSC in keeping international peace and security. The Treaty also does not influence the right of neutrality."This Treaty shall be open for signature by all States of the Euro-Atlantic and Eurasian space from Vancouver to Vladivostok as well as by the following international organizations": the OSCE, EU, NATO, CSTO and CIS (The Draft of the European Security Treaty, 2009, Art. 10).

In 2010, Moscow received 21 replies after sending the draft of the Treaty to the heads of the recipient governments. In their replies, mostly, the recipient states were addressing the blurriness of the Treaty and wanting more detailed clarifications on it (Zagorski, 2017). ${ }^{14}$ Nonetheless, there was an option to update and upgrade the first draft of the proposal as it was an open dialogue initiative and not the ultimatum, but Moscow decided to leave it as it was, as it did not conduct any further actions to bring the proposal to the agenda again. Since then, the EST was not discussed anymore and wholly left the agenda of the architecture of the ESS, opening these condwave of the bargain.

The debate on the issue was continued in the Greek island, Corfu, in 2009, when after the informal OSCE ministerial meeting was decided to launch the 'Corfu Process.' The goal was to tackle the security challenges ${ }^{15}$ and to restore the trust and process, the discussions on the common and comprehensive security of the OSCE area. The agreement reached during the 'Corfu Process' was to process the dialogue on European security (OSCE, 2009).

The process was continued and additionally supported by Kazakh Chairmanship during the Astana OSCE summit when the "Astana Commemorative Declaration: Towards A Security Community 2010" was adopted. The participating States reaffirmed their commitment to all the previously adopted CSCE/OSCE documents, alongside with the concept of the Helsinki Final Act and "the vision of a free, democratic, common and indivisible Euro-Atlantic and Eurasian security community stretching from Vancouver to Vladivostok, rooted in agreed principles, shared commitments and common

\footnotetext{
${ }^{14}$ Only Cyprus was in favor of signing the Document.

${ }^{15}$ Including the 'protracted conflicts' and CFE suspension. 
goals." (Astana Commemorative Declaration: Towards A Security Community 2010, Art. 1, 2).It was welcoming any initiative targeting the strengthening of European security and continuation of the 'Corfu Process' (Astana Commemorative Declaration: Towards A Security Community, 2010, Art. 11).

The discussions were continued under the Lithuanian and Irish Chairmanships in 2011 and 2012, respectively. Under the Irish Chairmanships, the 'Helsinki +40 ' process was launched, and in the same year, Helsinki +40 Decisions made. While the substantive issues concerning the more obvious divide among member states were not addressed, but it provided a more specific timeframe about the upcoming three years. The agenda of the eight created working groups in 2013 were in many instances, similar to the one of the 'Corfu Process' (Liechtenstein, 2013).

2015 might have been the focal point for the architecture of the ESS, as there have been reasonable hopes for the pan-European summit during the $40^{\text {th }}$ anniversary of the Helsinki Final Act. Consensus could have been reached on the issues that were hovering around the continent for decades. Plus, many hopes were connected with the decisiveness of the Austrian chairmanship. Nonetheless, the Ukraine crises halted the process in 2014, and the bargain for the architecture of the ESS is remaining frozen nowadays, and that narrows Russian strategic choices and leave with the viable option of strengthening the existing status quo via regional integration.

\section{Strengthening the Status Quo via Integration}

The window for Russia to consolidate the post-soviet space with its perceived status-quo becomes the period of the enlargement processes of NATO and the EU 1997-2007.In 2013, the EU launched the 'Eastern Partnership' program for the post-Soviet States, which pushed Russia to accomplish the integrational processes even quicker.

After the dissolution of the USSR, the CIS was immediately launched, aiming to set the process of the other regional integration in the post-Soviet space. Regardless of the ambitious economic aims of the CIS, it did not succeed. ${ }^{16}$ Plus, other approaches since the 1990 s were halted due to insufficient economic resources as well as rivalries and political dissensions between the post-Soviet states and even leaders. The first real, highly institutionalized approach of Russia to consolidate the post-Soviet space became the EU project-inspired Eurasian Economic Community (EurAsEC) with the highly legalized framework. It brings coordinated, and agreed policies during the creation of the common market ruled and inspired by economic convergence criteria and broad multilateralism (Vicari, 2016).

After the predictable exit of Ukraine from the project of the Common Economic Space, the three states, Russia, Belorussia and Kazakhstan, decided to continue the project on their own, more decisively and in a shorter period. In 2009, they established the appropriate steps for the establishment of the Customs Union (CU) and then in 2011, already started the process of the formation of the Eurasian Economic Union (EAEU) for the states of the CU. In 2011, the agreements were ready and entered into the force next year. In 2014, the Treaty of EAEU was signed and came into force from January 1, 2015.In 2015, the EAEU was joined by Armenia and Kyrgyzstan. The EAEU became the first comparatively successful multilateral supranational integrational institution. To accomplish it, Russia needed the consolidated geographical area of the post-Soviet space to create the second pillar, the Eurasian community of the system of the post-Soviet space. In comparison to the previous projects, it has greater supra nationalism. All supranational institutions ${ }^{17}$ are based on the formal recognition of the equality between the member states (Busygina \& Filippov, 2018).

\footnotetext{
${ }^{16}$ Mostly because of the institutional design of the organization.

${ }^{17}$ Eurasian Economic Commission, intergovernmental Council, EAEU Supreme Council and the Court of Justice.
} 
The military integration or the military pillar of the Russian consolidation of the post-Soviet space started with the adoption of Collective Security Treaty (CST) in 1992,whichcame into force in 1994 and until 1999 involved the 9 out of 12 post-Soviet states. ${ }^{18}$ The Treaty had a defence clause similar to Article 5 of NATO. Article 4 pointed out that the attack against any member state means an attack on everyone. The CST was abandoned in the late 1990s after Georgia, Azerbaijan and Uzbekistan refused to prolong their membership. Being an integral part of the CIS system, it was predominantly the collective defence treaty aimed to counter the external threats presented by other states (Nikitina, 2013).

The next round was to establish an institutionalized military organization. In 2002, the CSTO was launched by Russia, Belorussia, Kazakhstan, Armenia, Tajikistan and Kyrgyzstan. The institutionalization and in-depth cooperation expanded in the 2000s.It is gradually becoming a multifunctional and multipurpose collective security organization similar to NATO. Nonetheless, still, it did not carry any field operations or missions. ${ }^{19}$ The CSTO, like its predecessor, is predominantly the collective defence organization dealing with external threats with reservations to intervene in the internal crises (Nikitina, 2013).

The CSTO is the military pillar of the broader consolidation processes of the post-Soviet space around Russia. Russia does not align itself with the post-Soviet much weaker states to be able to protect itself from the direct external threat. ${ }^{20}$ The main Russian goal here is the containment of NATO from aligning with the post-Soviet states. ${ }^{21}$ By doing so, Russia creates a solid ground for its military dominance in the region by taking under its security umbrella the post-Soviet space and tracing 'red line.'

So, as it could be assumed, Russia actually was working on the reintegration of the post-Soviet space immediately after the Soviet disintegration. Starting from the rule of Boris Yeltsin and continuing with the one of Vladimir Putin, it is on the agenda of the Russian Federation, just the forms might vary. Russia did not reconcile itself with the consideration of losing the sphere of influence and its domination in the post-Soviet space, that is why the Soviet disintegration ended with the start of the CIS (Blank, 2014). ${ }^{22}$

\section{CONCLUSIONS}

The evolution of Russia-West bargain for European security architecture is the reflection of the changing nature of Russia-West changing relations and Russian strategic choices since the end of the Cold War. This trend reflected in the construction of the regime. In the 1990s, in Russia and the West, the decision was made in favour of the Russian integration to the Political West, based on shared values, interests and equal strategic partnership with the lead of OSCE. However, at the same time, it was not abandoning the option of strengthening the status quo of the post-Soviet space. This policy would not necessarily contradict the option of Russian integration with the Political West, as alongside with Russian integration, the formations of the post-Soviet space would be integrated too. Nowadays, Russian adjustment changed dramatically and it is more about strengthening the existing status quo through the integration and consolidation of the post-Soviet states around it, which results in the self-establishment as an independent centre of power in the international arena.

\footnotetext{
18 Turkmenistan, Ukraine and Moldova.

${ }^{19}$ NATO carried out its first joint operation in 1990.

${ }^{20}$ Russia could defend itself without them.

${ }^{21}$ That is why the cooperation between NATO and different post-Soviet republics have a strictly bilateral basis.

${ }^{22}$ Even in August 2008, after the Russo-Georgian war, President Dmitry Medvedev explicitly announced that Russia has privileged interests in some countries, without specifying them.
} 
The change of the vector and strategic choice established a new context, where the Eurasian integration was developing. The strengthening of the existing status quo and establishing official relations between the NATO and CSTO as well as EU and EAEU, Russia re-institutionalized its participation in the ESS. However, the limitation of the geographical zones of responsibility between the Euro-Atlantic and Eurasian communities inevitably brings back the bipolar, Yalta style reminding architecture of the ESS, when the allies recognized the sphere of influence of the USSR in Eastern Europe. It presumes limitation of spheres of interests by drawing a 'red line' between Euro-Atlantic and Eurasian communities based on mutual agreement and the national interests instead of the shared ones, so more into the 'New Yalta' style. In fact, the debate developed at the end of the 2000s was about the Russian attempt to establish the bipolar architecture of the ESS based on cooperation between the two communities of states, Euro-Atlantic and Eurasian and was presuming the agreement on the 'red line' that the NATO and EU should not cross during their enlargement processes.

The in-depth and intensified regional integrational processes are the only way for Russia to strengthen the existing status quo, while the strengthening of the existing status quo is the only viable strategic option to adjust the State in the architecture of the ESS and have relative gains. For Russia, the post-Cold War status quo means non-alignment or nonintegration of the post-soviet countries with the Euro-Atlantic structures. By this, two-dimensional integration, Russia creates the second pillar, the Eurasian pillar, which alongside the Euro-Atlantic one, inevitably brings back the bipolar or 'New Yalta' styled architecture of the ESS.

\section{REFERENCES}

1. Astana Commemorative Declaration: Towards A Security Community. (2010, December 3). Art. 1, 2, 11. Retrieved from: https://www.osce.org/mc/74985?download=true

2. Blank, S. (2014). The Intellectual Origins of the Eurasian Union Project. In S. F. Starr \& S. E. Cornell (Eds), Putin's Grand Strategy: The Eurasian Union and Its Discontents. 14-15. Central Asia-Caucasus Institute \& Silk Road Studies Program. Retrieved from: http://silkroadstudies.org/resources/1409GrandStrategy.pdf

3. Bucharest Summit Declaration. (2008, April 3). Art. 23. Retrieved from: https://www.nato.int/cps/en/natohq/official_texts_8443.htm?selectedLocale=en

4. Busygina, I. \&Filippov, M. (2018). Russia and the Eurasian Economic Union: Between Bilateral and Multilateral Relations. Swedish Institute of International Affairs: Ulbrief NO 9, 2. http://dx.doi.org/10.2139/ssrn.3298743

5. Istanbul Document 1999. (1999, November 19). Charter For European Security. Chapter 3, Art. 12. Retrieved from: https://www.osce.org/mc/39569?download=true

6. Kelin, A. (2015). The Osce is Finally Working as How Always it Should Work. Security Index 3(114), 18. (Келин, А. ОБСE Наконеи-ТоРаботаетТак, КакДолжнаБылаРаботатьВсегда.ИндексБезопасности, №3 (114)). Retrieved from: http://www.pircenter.org/media/content/files/13/14482852520.pdf

7. Kile, S. N. (2001, June). Missile Defence and the ABM Treaty: A Status Report. Sipri Fact Sheet. Retrieved from: https://www.sipri.org/publications/2001/sipri-fact-sheets/missile-defence-and-abm-treaty-status-report

8. Kremlin. (2009, April 20). Speech at the University of Helsinki and answers to questions from the audience (Kpeмль Президент России. Выступление в Университете Хельсинки и ответь на вопросы аудитории). Retrieved from: http://www.kremlin.ru/events/president/transcripts/3805 
9. Kremlin. (2016, May 27). Joint press conference with Greek Prime Minister Alexis Tsipras (Кремль - Президент России. Совместная пресс-конференция с Премьер-министром Греции Алексисом Ципрасом). Retrieved from: http://www.kremlin.ru/events/president/news/52024

10. Liechtenstein, S. (2013, December 27). The Helsinki+40 Process: Determining the Future of the OSCE. ETH Zurich: Center for Security Studies. Retrieved from:https://isnblog.ethz.ch/international-relations/the-helsinki40-process-determining-thefuture-of-the-osce

11. Lyne, R. (2015). Russia's Changed Outlook on the West: From Convergence to Confrontation. In Giles, K., Hanson, P., Lyne, R., Nixey, J., Sherr, J. \& Wood, A. (Eds), The Russian Challenge. Chapter 2. Gratham House Report: The Royal Institute of International Affairs. Retrieved from: https://www.chathamhouse.org/sites/default/files/field/field_document/20150605RussianChallengeGilesHansonLyneNixeySher rWoodUpdate.pdf

12. Mandelson, P. (2007, April 20). The EU and Russia: our joint political challenge. Conference in Bologna: "The Future relationship between Russia and the European Union: Which kind of opportunities for the Italian economy?". SPEECH/07/242. Retrieved from: https://ec.europa.eu/commission/presscorner/detail/en/SPEECH_07_242

13. Nikitina, Y. (2013). Security cooperation in the Post-Soviet area within the Collective Security Treaty Organization. ISPI analyses No152, 2-5. Retrieved from: https://www.ispionline.it/it/documents/Analysis_152_2013.pdf

14. OSCE. (2003, December 7). International Election Observation Mission. Retrieved from: https://www.osce.org/odihr/elections/russia/18284?download=true

15. OSCE. (2009, June 28). 'Corfu Process' launched to take European security dialogue forward, says OSCE Chairperson. Retrieved from: https://www.osce.org/cio/51105

16. Perez-Rivas, M. (2001, December 14). U.S. quits ABM treaty. CNN. Retrieved from: http://www.cnn.com/2001/ALLPOLITICS/12/13/rec.bush.abm/

17. TASS. (2018, March 2). Putin says arms race between US, Russia followed Washington's withdrawal from ABM Treaty. Retrieved from: https://tass.com/politics/992402

18. The Draft of the European Security Treaty. (2009, November 29). Art. 1, 2.1, 2.2, 3.1, 4, 6.3, 7.2, 8.1, 8.4, 9.1, 9.4, 10. Retrieved from: http://en.kremlin.ru/events/president/news/6152

19. Vicari, M. S. (2016). The Eurasian Economic Union-Approaching the Economic Integration in the Post-Soviet Space by EUEmulated Elements. Revue Interventions économiques/Papers in Political Economy 55, 11-12. DOI: 10.4000/interventionseconomiques.2823 PUBLISHED BY THE SWEDISH INS

20. Weitz, R. (2015, March 17). After Russia's Exit, Time for West to Close the Book on CFE Treaty. World Politics Review. Retrieved from: https://www.worldpoliticsreview.com/articles/15307/after-russia-s-exit-time-for-west-to-close-the-book-oncfe-treaty

21. Zagorski, A. (2009). The Russian Proposal for a Treaty on European Security: From the Medvedev Initiative to the Corfu Process. OSCE Yearbook 2009, 43. Retrieved from: https://ifsh.delfile-CORE/documents/yearbook/english/09/Zagorski-en.pdf

22. Zagorskii, A. V. (2017). Russia in the European Security Order. Series "Library of the National Research Institute world economy and international relations named after E.M. Primakova” 143, 25-31, 75-79, 82-83, 86. Moscow, IMEMO. ( Загорский, А.В. Россия В СистемеЕвропейскойБезопасности. Серия «БиблиотекаНациональногоисследовательскогоинститутамировойэкономики и международныхотношенийимени E.M. Примакова».3аго 143). DOI:10.20542/978-5-9535-0524-6 TUTE 


\section{AUTHOR PROFILE}

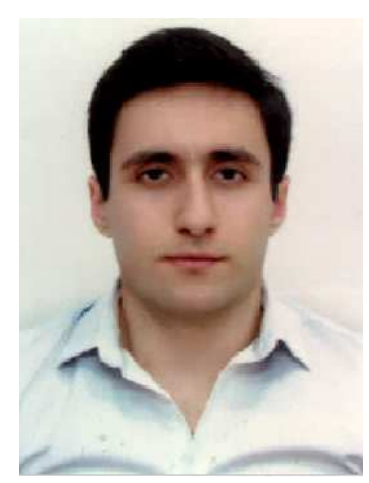

Mr. AvetikPashayan, studied International Relations at the Sofia University named "St. KlimentOhridski" in Bulgaria as a bachelor student. Then he acquired his Master's degree in International Relations at the University of Ljubljana, Slovenia, in 2015. Since 2016, he is doing a four years Ph.D. program in International Politics/Relations at the Shandong University in the People's Republic of China. He has done research works and presentations in the area of international relations with a focus on Russian foreign politics as well as governance and security systems of European and Arctic regions. 